\title{
Kontrol Diri Siswa Terhadap Kecanduan Media Sosial
}

\author{
Yuliastri Ambar Pambudhi, ${ }^{1}$ Ardenal Pata ${ }^{2}$, \& Aspin ${ }^{3}$ \\ Jurusan Psikologi \\ Fakultas Keguruan dan Ilmu Pendidikan, Universitas Halu Oleo \\ yul_psy@yahoo.co.id ${ }^{1}$, ardenalpd@gmail.com², aspin.psi@gmail.com ${ }^{3}$
}

\begin{abstract}
Abstrak : Kecanduan media sosial adalah ketidakmampuan individu dalam mengontrol perilaku mengakses media sosial sehingga menyebabkan masalah psikologis dan mengabaikan aktivitas lain seperti studi dan pekerjaan lainnya. Setiap individu mempunyai mekanisme yang dapat mengatur dan mengarahkan perilakunya yang disebut kontrol diri. Penelitian ini bertujuan untuk mengetahui apakah terdapat peran kontrol diri terhadap kecanduan media sosial pada siswa kelas XII SMKN 1 Kendari dan seberapa besar sumbangan efektif peran kontrol diri terhadap kecanduan media sosial pada siswa kelas XII SMKN 1 Kendari. Subjek dalam penelitian ini berjumlah 54 orang siswa kelas XII SMKN 1 Kendari yang kecanduan media sosial dengan menggunakan teknik total sampling. Instrumen penelitian ini menggunakan skala kontrol diri dan skala kecanduan media sosial yang disebar secara online dengan menggunakan google form. Jenis penelitian ini yaitu kuantitatif dengan desain penelitian Ex-Post Facto. Data penelitian dianalisis menggunakan analisis regresi sederhana. Hasil penelitian dengan taraf signifikansi sebesar 0,037 menunjukkan bahwa kontrol diri berperan sangat signifikan terhadap kecanduan media sosial. Nilai $R$ square sebesar 0,081, artinya sumbangan efektif kontrol diri terhadap kecanduan media sosial sebesar $8,1 \%$. Berdasarkan hasil penelitian ini, terdapat peran kontrol diri terhadap kecanduan media sosial
\end{abstract}

Kata Kunci : kecanduan media sosial; kontrol diri; siswa

\begin{abstract}
Social media addiction is an individual's inability to control their behaviour in accessing social media, causing psychological problems and ignoring other activities such as other work. Every individual has a mechanism that can regulate and direct their behaviour called self-control. This study aims to determine whether there is a role for self-control on social media addiction in class XII students of SMKN 1 Kendari and how much of an effective contribution to the role of self-control on social media addiction in class XII students of SMKN 1 Kendari. The subjects this study were 54 students of class XII SMKN 1 Kendari who are addicted to social media using total sampling technique. The research instrument uses a self-control scale and a scale of social media addiction which is distributed online using google form. This type of research is quantitative with an Ex-Post Facto research design. The research data were analyzed using simple regression analysis. The results of the study with a significance level of 0.037 indicate that self-control plays very significant role in social media addiction. The $R$ square value is 0.081 , meaning that effective contribution of selfcontrol to social media addiction is $8.1 \%$. Based on the results of this study, there is a role for self-control in social media addiction.
\end{abstract}

Keywords : self control; social media addiction; students 


\section{Pendahuluan}

Gawai dan internet (interconnected network) adalah kebutuhan yang sudah menjadi sangat penting bagi setiap orang saat ini dan tidak bisa lagi dipisahkan dari rutinitas penggunanya. Internet juga telah mengubah cara interaksi sosial manusia dengan sedemikian rupa untuk terhubung ke banyak individu (Al-menayes, 2014). Internet menyediakan sarana mempercepat interaksi berbasis online salah satunya adalah media sosial. Sebagian orang rela menghabiskan banyak waktu untuk mengakses media sosialnya. Media sosial memberikan kemudahan bagi para penggunanya untuk saling berinteraksi, melihat informasi serta mengekspresikan diri.

Menurut Kemp (2020) media sosial yang paling banyak digunakan di dunia adalah Facebook, Youtube, Whatsapp, Messenger, Instagram, Wechat, dan Tiktok Sedangkan media sosial yang paling banyak digunakan di Indonesia adalah Youtube, Whatsapp, Facebook, Instagram, Twitter dan Tiktok. Khususnya bagi kalangan remaja yang saat ini menggunakan media sosial untuk memperoleh informasi terbaru, sebagai hiburan dan tempat untuk saling berinteraksi dengan teman ataupun pengguna media sosial lainnya dengan menggunakan beberapa media sosial yang populer saat ini yaitu Youtube, Whatsapp, Facebook, Instagram, Twitter dan Tiktok. Media sosial selain digunakan sebagai sarana untuk berinteraksi yaitu berbagi informasi dan mendapatkan informasi, juga tempat untuk memperluas hubungan sosial para penggunanya, juga menjadi ruang dimana individu membentuk dan membangun hubungan dengan pengguna media sosial lainnya, serta mengekspresikan dirinya.

Penelitian yang dilakukan Kemp (2020) menyatakan bahwa pengguna aktif media sosial orang Indonesia sebanyak 160 juta menghabiskan waktu 3 jam 26 menit perharinya untuk melakukan akses media sosial. Pengguna media sosial ini didominasi golongan usia 18-24 tahun.

Penelitian juga dilakukan oleh Irawan, Yusufianto, Agustina \& Dean (2019) yang menyatakan bahwa jumlah pengguna internet di Indonesia mencapai 196,71 juta jiwa. Pengguna internet didominasi usia 15-19 tahun dan menggunakan rata-rata waktu untuk mengakses media sosial sekitar 4-5 jam perharinya.

Riset juga dilakukan oleh Smith \& Koray (2018) menunjukkan bahwa usia pengguna media sosial rata-rata 15-24 tahun dan menghabiskan waktu untuk mengakses media sosial 6 jam 46 menit per hari.

Hasil survei di atas menunjukkan bahwa media sosial saat ini sudah menjadi kebutuhan bagi orang-orang. Usia pengguna media sosial juga didominasi oleh remaja. Fenomena di kalangan remaja saat ini adalah mereka sangat gemar bermedia sosial dengan gawai yang dimiliki dengan tujuan agar para remaja dapat terhubung terus dengan media sosialnya dengan aktivitas memperbaharui, melihat dan mengomentari status dan berbagi informasi pada media sosial yang dimiliki seolah-olah sangat penting (Juwita, Budimansyah \& Nurbayani, 2015).

Remaja merupakan masa perkembangan transisi antara anak-anak dan masa dewasa yang didalamnya mencakup kematangan mental, emosional, sosial dan fisik (Hurlock, 1980). Menurut Piaget (dalam Hurlock, 1980) secara psikologis, masa remaja adalah usia dimana individu bergabung dengan masyarakat dewasa, usia dimana remaja menginginkan dirinya dianggap sama seperti orang dewasa. Dalam masa ini, 
diharapkan remaja dapat menggunakan cara yang positif untuk mencapai kematangan individu yang baik. Akan tetapi tidak semua remaja dalam mencari identitas diri menunjukkan perilaku yang positif untuk menunjukkan eksistensi dirinya agar mendapat perhatian dari orang lain. Salah satu cara yang dilakukan oleh remaja adalah menjadi pengguna aktif di media sosial. Remaja akan menjelajah dan menunjukkan diri mereka kepada orangorang atau pengguna lainnya dengan memposting foto, membuat status dan berbagi informasi berupa video dan katakata motivasi pada media sosial yang mereka miliki. Biasanya para remaja membuat kutipan kata atau mendeskripsikan pada foto yang diunggah dengan semenarik mungkin supaya dapat menarik perhatian pengguna media sosial lainnya agar memberikan komentar atau tanda menyukai pada foto, video dan informasi yang diunggah. Perilaku mengakses media sosial dengan intensitas yang semakin sering dan tanpa batas dapat mengganggu perkembangan diri seorang remaja sebagai pelajar.

$$
\text { Siddiqui \& Singh (2016) }
$$

menyatakan bahwa penggunaan media sosial bagi siswa memiliki manfaat yang positif yaitu siswa dengan mudah dapat berinteraksi dan berbagi informasi tentang tugas-tugas sekolah, kegiatan usaha kelas, dukungan dari teman-teman dan pekerjaan rumah secara cepat melalui media sosial masing masing dan juga disamping itu memiliki manfaat negatif yakni siswa dapat mengabaikan tugas sekolah, mengakses media sosial pada saat jam pelajaran dan juga memposting hal-hal yang bersifat privasi di media sosialnya.

Menurut Al-menayes (2015) remaja yang mengakses media sosial secara berlebihan dapat berdampak negatif terhadap psikologisnya seperti kurang tidur dan mengabaikan tugas sekolahnya. Hal tersebut dilakukan oleh remaja karena usia mereka yang masih belum berpengalaman dan masih memiliki keterbatasan dalam pengendalian diri saat menghadapi masalah (O’Keeffe\& Pearson, 2011).

Remaja akan secara terus menerus melakukan aktivitas di media sosial karena adanya perhatian dari pengguna lainnya dan kepuasan diri yang didapatkan yang membuat kebutuhan mereka terpenuhi. Felita, Siahaja, Wijaya, Melisa, Chandra \& Dahesihsari (2016) menyebutkan bahwa empat alasan utama remaja sangat menyukai media sosial diantaranya; untuk mendapatkan perhatian, untuk meminta respon kepada pengguna lainnya dari apa yang telah diposting, menumbuhkan citra dan kecanduan.Aprilia, Sriati\&

Hendrawati (2020) menyatakan bahwa remaja cenderung menggunakan media sosial untuk memenuhi keingintahuan terhadap berbagai hal yang terdapat pada media sosial dan juga karena media sosial sedang menjadi trend di kalangan sebayanya. Leung (2007) menunjukkan hasil penelitiannya mengenai motif pada pengguna berat media sosial khususnya pada remaja adalah untuk memodifikasi suasana hati seperti mencari hiburan dan memperoleh pengakuan dari pengguna lainnya sehingga berdampak mengurangi interaksi sosial. Akibatnya individu mendapatkan keluhan dari orang sekitar karena mengakses media sosial terlalu lama.

Hasil penelitian dari Irawan, Yusufianto, Agustina \& Dean (2019) ditemukan data bahwa sebanyak 36,5 juta pengguna internet berusia 10-24 tahun dan 11,2 juta diantaranya adalah pelajar sekolah. Pelajar atau peserta didik yang berusia 15-17 tahun yang duduk di bangku sekolah menengah atas telah mengikuti proses pendidikan dan pembelajaran untuk meningkatkan pengetahuan dan pengembangan diri baik secara sosialemosional, moral maupun intelektual. Remaja pada masa ini ingin selalu menjadi 
pusat perhatian, menonjolkan diri dan memantapkan identitas dirinya.

Menurut Erikson (dalam Hurlock, 1980) pencarian identitas diri remaja berupa usaha untuk dapat menjelaskan siapa dirinya, apa perannya di dalam lingkungan masyarakat dan apakah individu tersebut seorang anak-anak atau seorang dewasa. Remaja akan melalui masa krisis dimana remaja berusaha untuk mencari identitas dirinya. Krisis identitas diri remaja menyebabkan beberapa kondisi penurunan moral yang tidak terkontrol diantaranya; kekerasan, kata-kata yang buruk, meningkatnya perilaku merusak diri dan menurunnya rasa hormat pada orang tua dan guru.

Saat ini akses media sosial yang cukup mudah dan murah menjadikan pengunaan media sosial bersifat tanpa batas, khususnya di kalangan siswa yang dengan sangat mudah untuk menjelajah di media sosial secara terus menerus untuk mencari berbagai informasi dan mengekspresikan diri demi mendapatkan pengakuan dan kepuasan. Norlina (2019) pengaksesan media sosial tanpa dikontrol dengan baik akan menyebabkan penggunanya bersifat kecanduan. Straeck (2018) menyebutkan media sosial sebagai bagian yang konstan dari kehidupan siswa akan berakibat pada kecanduan media sosial. Wulandari \& Netrawati (2020) menyatakan kemudahan dalam menggunakan media sosial menjadikan media sosial suatu kebutuhan yang harus ada bagi setiap penggunanya di manapun mereka berada, hal ini menjadikan suatu kebiasaan bagi para penggunannya dan secara tidak langsung mengakibatkan penggunanya mengalami masalah kecanduan.

Menurut Griffiths \& Kuss (2017) berbagai macam fitur yang terdapat pada situs media sosial dapat menjadi salah satu penyebab kecanduan media sosial, terutama padameningkatnya waktu penggunaan media sosial. Individu dapat dikatakan menggunakan media sosial dengan intensitas yang tinggi bahkan kecanduan jika memiliki kriteria: (1) salience hal ini terjadi ketika penggunaan media sosial menjadi aktivitas yang paling penting dalam kehidupan individu, mendominasi pemikiran individu (preokupasi dan distorsi kognitif) dan perasaan merasa sangat butuh; (2) mood modifications hal ini mengarah pada pengalaman individu sendiri, yang menjadi hasil dari pengaksesan media sosial sebagai media untuk melupakan masalah; (3) tolerance hal ini merupakan proses dimana terjadinyapeningkatan waktu penggunaan media sosial untuk mendapatkan efek perubahan dari mood; (4) withdrawal symptoms halini merupakan perasaan tidak menyenangkan yang terjadi karena penggunaan media sosial dikurangi atau tidak dilanjutkan; (5) conflict hal ini mengarah pada konflik yang terjadi antara pengguna media sosial dengan lingkungan sekitarnya (konflik interpersonal) atau konflik yang terjadi dalam dirinya sendiri (intrapsikis); (6) relapse hal ini merupakan kecenderungan berulangnya kembali pola penggunaan media sosial setelah adanya kontrol untuk berhenti menggunakan media sosial.

Menurut Almenayes (2015) kecanduan media sosial adalah perilaku penggunaan media sosial secara berlebihan dan menghabiskan banyak waktu dan mengorbankan kegiatan lainnya. Menurut Kootesh, Raisi \& Ziapour (2016) kecanduan media sosial adalah ketidakmampuan individu untuk mengontrol perilaku mengakses media sosial dan menjadi berlebihan sehingga menyebabkan masalah psikologis dan interaktif.

Andreassen (2015) mengatakan bahwa kecanduan media sosial adalah 
perilaku berlebihan mengakses media sosial yang didorong oleh motivasi untuk terus menggunakan media sosial dan menghabiskan banyak waktu sehingga mengganggu aktivitas sosial, studi dan hubungan interpersonal lainnya.

Lestari, Dewi \& Chairani (2020) menyebutkan kecanduan media sosial merupakan gangguan psikologis yang ditandai dengan perilaku mengakses media sosial dengan menghabiskan banyak waktu yang disebabkan kurangnya kontrol diri. Dampak negatif dari kecanduan media sosial siswa dapat mengganggu kegiatan akademis dan kehidupan sosial siswa (Khan, 2018). Fenomena itulah yang terjadi pada siswa kelas XII SMKN 1 Kendari, dimana mengakses media sosial yang mereka miliki sudah menjadi hal yang sangat penting dalam kehidupan mereka.

Berdasarkan survei yang dilakukan peneliti terhadap 371 siswa kelas XII didapatkan data bahwa sebanyak 54 siswa yang mengakses media sosial lebih dari 6 jam perhari, mereka lebih banyak menggunakan waktu mengakses media sosial untuk mencari hiburan dibandingkan waktu untuk belajar, merasa cemas, gelisah dan tidak bisa tidur ketika tidak dapat mengakses media sosial bahkan ketika sedang dalam jam pelajaran mereka bermain media sosial. Berdasarkan informasi yang diperoleh dari guru bimbingan konseling di SMKN 1 Kendari bahwa beberapa siswa yang berurusan dengan guru bimbingan konseling adalah siswa yang mayoritas berasal dari kelas XII dan kedapatan menggunakan gawai serta mengakses media sosial ketika sedang dalam proses belajar di kelas.

Siswa yang terlalu asik dengan media sosialnya biasanya lupa akan waktu berkomunikasi dengan orang-orang yang bersama dengannya, lupa dengan tugastugas sekolah dan tugas-tugas rumah demi mengakses media sosial. Hal ini mereka lakukan karena mereka merasa bahwa mudahnya mengakses media sosial membuat mereka terlepas dari rasa jenuh yang mereka alami.

Kegiatan mengakses media sosial yang berlebihan akan berakibat buruk bagi siswa. Dalam menggunakan media sosial setiap individu seharusnya dapat mengontrol dirinya agar menggunakannya dengan bijaksanadan tidak menggunakannya secara berlebihan. Kemampuan mengontrol diri sangat diperlukan di kalangan siswa saat ini, dikarenakan dalam masa ini akan begitu banyak dorongan-dorongan keinginan untuk mengakses media sosial yang bergejolak.

Setiap individu memiliki kontrol diri yang dapat mengatur dan mengarahkan perilakunya. Muna \& Astuti (2014) menyatakan kecanduan dalam penggunaan media sosial dapat dipengaruhi oleh beberapa faktor, salah satunya adalah faktor kontrol diri.

Menurut Ghufron \& Risnawita (2017) kontrol diri merupakan kemampuan untuk menyusun, membimbing, dan mengarahkan bentuk perilaku yang dapat membawa ke arah konsekuensi positif. Kontrol diri juga adalah suatu kecakapan individu dalam membaca situasi diri dan lingkungannya.

Averill (dalam Ghufron \& Risnawita, 2017) mengatakan kontrol diri sebagai kontrol personal, yaitu kemampuan individu untuk memodifikasi perilaku (behaviour control), kemampuan individu dalam mengelola informasi yang tidak diinginkan dengan cara menginterpretasi dan menilai (cognitive control), serta kemampuan individu untuk memilih suatu tindakan berdasarkan suatu yang diyakini (decisional control). Kontrol diri yang baik akan membuat individu berperilaku disiplin dan terhindar dari perilaku impulsif (Adlya, Yusuf \& Effendi, 2020). 
Adapun penelitian yang relevan dengan penelitian ini yaitu penelitian yang dilakukan Shindia, Mamesa dan Djunaedi (2014) tentang pengaruh kontrol diri terhadap kecanduan media sosial Facebook pada siswa. Hasil penelitian ini menunjukkan bahwa terdapat peran kontrol diri yang positif dan signifikan terhadap kecanduan media sosial siswa.

Penelitian yang dilakukan Wulan (2020) tentang pengaruh kontrol diri terhadap kecanduan media sosial pada remaja menunjukkan bahwa kontrol diri berperan positif dan signifikan terhadap kecanduan internet pada remaja. Penelitian juga dilakukan oleh Ritonga, Mudjiran \& Kiram (2018) tentang kontrol diri dan kecanduan media sosial. Hasil penelitian menunjukkan terdapat peran yang signifikan kontrol diri terhadap kecanduan media sosial pada siswa.

Rumusan masalah dalam penelitian ini adalah apakah ada peran kontrol diri terhadap kecanduan media sosial pada siswa kelas XII SMKN 1 Kendari.

Berdasarkan rumusan masalah yang diuraikan, tujuan penelitian yang ingin dicapai dari penelitian ini adalah apakah ada peran kontrol diri terhadap kecanduan media sosial pada siswa kelas XII SMKN 1 Kendari.

Hipotesis dalam penelitian ini adalah terdapat peran kontrol diri terhadap kecanduan media sosial pada siswa kelas XII SMKN 1 Kendari.

\section{Metode Penelitian}

Penelitian ini merupakan penelitian kuantitatif dengan menggunakan desain penelitian ex-post facto. Variabel dalam penelitian ini adalah variabel kontrol diri sebagai variabel bebas dan variabel kecanduan media sosial sebagai variabel terikat.

Populasi dalam penelitian ini adalah siswa kelas XII SMKN 1 Kendari yang telah melewati proses screening dengan jumlah 54 orang. Teknik pengambilan sampel dilakukan dengan teknik total sampling sehingga sampel pada penelitian ini berjumlah 54 orang.

Metode pengumpulan data terdiri dari skala kontrol diri dan skala kecanduan media sosial. Skala kontrol diri terdiri dari pernyataan-pernyataan yang bersifat favorable dan unfavorable yang berisi 52 item pernyataan yang merupakan adaptasi dan modifikasi dari instrumen penelitian Kurniawan (2019) yang menghasilkan 40 item valid dengan reliabilitas sebesar 0,932. Skala tersebut disebar secara online melalui google form. Skala kecanduan media sosial terdiri dari pernyataanpernyataan yang bersifat favorable dan unfavorable yang berisi 48 item pernyataan yang merupakan adaptasi dan modifikasi dari instrumen penelitian Tiara (2018) yang menghasilkan 38 item valid dengan reliabilitas sebesar 0,911. Skala tersebut disebar secara online melalui google form.

Pengujian hipotesis dilakukan menggunakan analisis regresi sederhana dengan menggunakan program SPSS (Statistical Product and Service Solutions) 20.0. Pengambilan keputusan dalam analisis regresi sederhana yaitu membandingkan nilai signifikansi dengan nilai probabilitas 0,05 . Untuk mengetahui apakah data terdistribusi normal yaitu dengan menggunakan teknik kolmogorovsmirnov dan apakah jenis data tersebut linear yaitu dengan menggunakan test for linearity.

\section{Hasil Penelitian dan Pembahasan}

Uji normalitas variabel kontrol diri menunjukkan nilai signifikansi sebesar 0,667 sedangkan pada variabel kecanduan media sosial nilai signifikansi sebesar 0,937 . Nilai ini lebih besar dari 0,05 . Ini menunjukkan bahwa data variabel kontrol 
diri dan variabel kecanduan media sosial terdistribusi secara normal.

Tabel 1.Uji Normalitas

\begin{tabular}{lll}
\hline \multicolumn{3}{l}{ One-Sample Kolmogorov-Smirnov Test } \\
& Signifikansi & Keterangan \\
\hline Kontrol Diri & 0,667 & $\mathrm{P} \geq 0,05$ (Normal) \\
$\begin{array}{l}\text { Kecanduan Media } \\
\text { Sosial }\end{array}$ & 0,937 & $\mathrm{P} \geq 0,05$ (Normal) \\
\hline
\end{tabular}

Uji linearitas menunjukkan nilai signifikansi deviation from linearity sebesar 0,664. Nilai ini lebih besar dari 0,05 . Ini menunjukkan bahwa data variabel kontrol diri dan variabel kecanduan media sosial berhubungan secara linear.

Tabel 2. Uji Linearitas

\begin{tabular}{|c|c|c|}
\hline Variabel & $N$ & $\begin{array}{l}\text { Sig. Deviation } \\
\text { From Linearity }\end{array}$ \\
\hline $\begin{array}{l}\text { Kontrol Diri } \\
\mathrm{X}\end{array}$ & 54 & 0.664 \\
\hline $\begin{array}{l}\text { Kecanduan } \\
\text { Sosial }\end{array}$ & Media & \\
\hline
\end{tabular}

Uji hipotesis yang dilakukan dengan menggunakan analisis regresi sederhana menunjukkan nilai signifikansi 0,037. Nilai ini lebih kecil dari $p<0,05$ sehingga dapat dikatakan terdapat peran kontrol diri terhadap kecanduan media sosial. Dalam hal ini hipotesis yang diajukan diterima.

Tabel 3. Uji Analisis Regresi Sederhana

\begin{tabular}{lllll}
\hline Model & & \multicolumn{2}{l}{$\begin{array}{l}\text { Unstandardized } \\
\text { Coefficients }\end{array}$} & Sig \\
& & B & $\begin{array}{l}\text { Std. } \\
\text { Error }\end{array}$ \\
& & \multicolumn{3}{c}{} \\
& & & \\
& & & \\
& & & \\
& (Constant) & 133,703 & $.15,910$ & 0.000 \\
& Kontrol Diri & -.293 & .137 & 0.037 \\
\hline
\end{tabular}

Hasil analisis regresi koefisien menunjukkan nilai konstanta (a) sebesar 133.703 dan nilai koefisien regresi (b) sebesar -0,293. Persamaan regresi menunjukkan jika nilai variabel kontrol diri adalah 0, maka nilai variabel kecanduan media sosial sebesar 133.703. Nilai koefisien regresi sebesar $-0,293$ artinya jika variabel kontrol diri mengalami kenaikan 1 poin, maka variabel kecanduan media sosial akan mengalami penurunan sebesar 0,293 poin.

Analisis regresi sederhana pada model Summary menunjukkan $R$ Square sebesar 0,081 yang mengandung arti bahwa kontrol diri memberikan sumbangan efektif terhadap kecanduan media sosial sebesar $8.1 \%$.

Tabel 4. Koefisien Determinasi ( $R$ Square)

\begin{tabular}{llll}
\hline Model & $R$ & $R$ Square & Adjusted $R$ Square \\
\hline 1 & 0.284 & 0.081 & 0.063 \\
\hline
\end{tabular}

Berdasarkan hasil analisa di atas, diketahui bahwa kontrol diri berperan terhadap kecanduan media sosial. Hasil penelitian ini memiliki hasil yang sama dengan penelitian yang dilakukan oleh Shindia, Mamesha \& Djunaedi (2014). Hasil penelitian menunjukkan terdapat pengaruh yang signifikan kontrol diri terhadap kecanduan media sosial pada siswa. Penelitian juga dilakukan oleh Ritonga, Mudjiran \& Kiram (2018) tentang kontrol diri dan kecanduan media sosial. Hasil penelitian menunjukkan terdapat peran yang signifikan kontrol diri terhadap kecanduan media sosial pada siswa. Penelitian sejenis juga dilakukan oleh Wulan (2020) dimana hasil penelitian menunjukkan bahwa terdapat pengaruh yang signifikan kontrol diri terhadap kecanduan media sosial pada remaja.

Hasil penelitian ini menunjukkan bahwa kontrol diri merupakan salah satu faktor yang memberikan sumbangan efektif terhadap kecanduan media sosial. Averill (dalam Ghufron \& Risnawita, 2017) mengatakan kontrol diri sebagai kontrol personal, yaitu kemampuan 
individu untuk memodifikasi perilaku (behaviour control), kemampuan individu dalam mengelola informasi yang tidak diinginkan dengan cara menginterpretasi dan menilai (cognitive control), serta kemampuan individu untuk memilih suatu tindakan berdasarkan apa yang diyakini (decisional control). Ketiga aspek tersebut berperan penting dalam mengendalikan perilaku kecanduan mengakses media sosial. Siswa yang memiliki kontrol perilaku, kontrol kognitif dan kontrol pengambilan keputusan akan mampu mengatur perilakunya ketika mengakses media sosial.

Chaplin (2011) kontrol diri adalah kemampuan untuk membimbing tingkah laku sendiri serta kemampuan untuk menekan impuls-impuls atau tingkah laku impulsif.

Individu yang memiliki kontrol diri yang baik akan mampu mengatur perilakunya saat mengakses media sosial agar terhindar dari tingkah laku impulsif seperti menghabiskan banyak waktu untuk mengakses media sosial sebagai hiburan dan mengabaikan aktivitas-aktivitas lain yang lebih penting seperti studi dan pekerjaan lainnya.

\section{Kesimpulan}

Berdasarkan hasil penelitian yang telah dilakukan, dapat disimpulkan bahwa kontrol diri berperan secara signifikan terhadap kecanduan media sosial. Kontrol diri juga memberikan sumbangan efektif terhadap kecanduan media sosial.

Berdasarkan hasil penelitian yang diperoleh, peneliti memberikan informasi dan saran bagi pihak sekolah bahwa kontrol diri berpengaruh secara efektif terhadap kecanduan media sosial, untuk itu pihak sekolah perlu mengadakan webinar atau seminar sebagai edukasi tentang penggunaan media sosial yang bijak dan baik serta memaparkan dampak-dampak buruk dari penggunaan media sosial secara berlebihan di kalangan siswa. Memberikan informasi bagi siswa bahwa kontrol diri berpengaruh secara efektif terhadap kecanduan media sosial untuk itu diharapkan lebih meningkatkan kontrol dirinya saat sedang bermain media sosial seperti membatasi waktu mengakses media sosial, tidak mengakses media sosial ketika sedang mengikuti pembelajaran dan mampu membagi waktu antara mengakses media sosial dan waktu untuk belajar. Dan bagi peneliti selanjutnya yang tertarik dan akan melakukan penelitian dengan tema yang sama diharapkan untuk memastikan bahwa responden mengisi skala dengan fokus dan diharapkan agar sebaiknya meneliti variabel bebas yang lain yang mungkin memberikan sumbangan efektif yang lebih besar terhadap kecanduan media sosial.

Daftar Pustaka

Adlya, S. I., Yusuf, A. M., \& Effendi, Z. M. (2020). The contribution of self control to students discipline. Journal of Counseling and Educational Technology, 3 (1), 1-5.

Al-menayes, J. (2015). Psychometric properties and validation of the Arabic social media addiction scale. Journal of Addiction, 2015, 1-6.

Al-menayes, J. (2014). Religiosity and the perceived consequences of social media usage in a Muslim country. Journal of Arts and Humanities, 3 (5), 108-117.

Andreassen, C. S. (2015). Online social network site addiction; A comprehensive review. Journal of 
Technology and Addiction, 2, 175184.

Aprilia, R., Sriati, A., \& Hendrawati, S. (2020). Tingkat kecanduan media sosial pada remaja. Journal of Nursing Care, 3 (1), 41-53.

Chaplin, J.P. (2011). Kamus lengkap psikologi terjemahan Kartini Kartono. Jakarta: Rajawali Pers.

Felita, P., Siahaja, J., Wijaya, V., Melisa, G., Chandra, M., \& Dahesihsari, R. (2016). Pemakaian media sosial dan self concept pada remaja. Jurnal Ilmiah Psikologi Manasa, 5 (1), 3041.

Ghufron \& Risnawita. (2017). Teori-teori psikologi. Yogyakarta: Ar-ruz Media Group.

Griffiths, M.D. (2002). Using the internet for qualitative clinical research. Clinical Psychology, 10, 27-30.

Griffiths, M.D. \& Kuss.D.J. (2017). Adolescent social media addiction (revisited). Journal Education and Health, 35 (3), 49-52.

Hurlock, Elizabeth B. (1980). Psikologi perkembangan: Suatu pendekatan sepanjang rentang kehidupan (Edisi Kelima). Jakarta: Erlangga.

Irawan, A. W., Yusufianto, A., Agustina, D. \& Dean, R. (2019). Laporan survei internet APJII 2019-2020: Indonesia Survey Center [File data]. Diakses dari https://apjii.or.id/survei.

Juwita, E. P., Budimansyah, D \& Nurbayani, S. (2015). Peran media sosial terhadap gaya hidup siswa SMA negeri 5 Bandung. Jurnal Pendidikan Sosiologi, 5 (1), 1-8.
Kemp, S. (2020). Social media users pass the 4 billion mark as global adoption soars. We Are Social. Diakses dari https://wearesocial.com/blog/2020/0 4/digital-around-the-world-in-april2020.

Khan, N. T. (2018). Facebook addiction and its association with academic performance. Biomedical Journal of Scientific and Technical Research, 3 (5), 3523-3525.

Kootesh, B.R. Raisi, M \& Ziapour, A. (2016). Investigation of relationship internet addict with mental health and quality sleep in student. Acta Medica Mediterranea, 32, 19211924.

Kurniawan, B. F. P. (2019). Kontrol diri dalam penggunaan media sosial saat jam pelajaran pada siswi SMA. (Skripsi tidak dipublikasikan). Fakultas Keguruan dan Ilmu Pendidikan. Universitas Sanata Dharma. Yogyakarta.

Leung, L. (2007). Stressful life events, motives for internet use, and social support among digital kids. Cyber Psychology \& Behaviour, 10 (2).

Lestari, Y. M., Dewi, S. Y., \& Chairani, A. (2020). Hubungan alexithymia dengan kecanduan media sosial pada remaja di Jakarta Selatan. Scientific Medical Journal, 1 (2), 1-9.

Muna, R. F. \& Astuti, T. P. (2014). Hubungan antara kontrol diri dengan kecenderungan kecanduan media sosial pada remaja akhir. Jurnal Empati, 3 (4), 481-491.

Norlina. (2019). Hubungan antara intensitas penggunaan media sosial 
dan kontrol diri dengan smartphone addiction pada mahasiswa angkatan 2018 program studi bimbingan dan konseling FKIP Universitas Lambung Mangkurat. Jurnal Pelayanan Bimbingan dan Konseling, 2 (4), 193-198.

O'Keeffe, G. S., Clarke-Pearson, K., \& Council on Communications and Media. (2016). Clinical report - the impact of social media on children, adolescents and families. American Academy of Pediatrics Journal, 127 (4). 800-804.

Ritonga, R. S., Mudjiran \& Kiram, Y. (2018). Contribution of self-control and social skills on the tendency social media addiction. Global Conference Index, 2018, 1.

Shindia, Mamesha \& Djunaedi.(2014). Pengaruh self control terhadap kecanduan facebook pada siswa kelas VII, VIII dan IX. Jurnal Bimbingan dan Konseling, 30 (1).

Siddiqui, S. \& Singh, T. (2016). Social media its impact with positive and negative aspects. International Journal of Computer Applications Technology and Research, 5 (2). 71 75.

Smith, H., W \& Koray, E. (2018). Technology tracker [File data]. Diakses dari https://ipsos.com/sites/default/files/ct /publications/documents/201903/tech-tracker-q2-2018-final.pdf.
Straeck, A. (2018). Social media addiction in high school students: love joy high school. Diakses dari https://academia.edu/36598019/socia 1-media-addiction-in-high-schoolstudents.pdf.

Tiara, R. (2018). Hubungan kepribadian narsisitik dengan kecanduan media sosial pada remaja. (Skripsi tidak dipublikasikan). Fakultas Psikologi. Semarang.

Wulan, T.M. (2020). Pengaruh kontrol diri terhadap pengungkapan diri remaja akhir yang kecanduan Media Sosial. (Skripsi tidak dipublikasikan). Fakultas Psikologi. Surabaya.

Wulandari, R. \& Netrawati. (2020). Analisis tingkat kecanduan pada remaja. Jurnal Riset Tindakan Indonesia, 5 (2), 41-46. 